\title{
BEDIUZZAMAN SAID NURSI'S METHODOLOGY IN THE DISCOURSE OF MORAL EDUCATION IN HIS THEMATIC EXEGESIS, RASĀ'IL AL-NŪR
}

\author{
Betania Kartika Muflih \\ PhD candidate in the Faculty of Islamic Studies, Department of Qur'an Hadith, \\ University of Malaya, Malaysia \\ e-mail: anazain@gmail.com \\ Dato' M.Y. Zulkifli Haji Mohd Yusoff \\ An Academic staff of International Islamic University Malaysia (IIUM Holdings), \\ Lower Education Sdn .Bhd.
}

\begin{abstract}
This work investigates the approach used by Imam Bediuzzaman Said Nursi in the discourse on Islamic morality, and to understand his lively scriptural approach to the moral values in which it makes one's life meaningful and purposeful. This work is aimed to highlight distinctive aspects and features of his approach and methodology used in his Qur'anic exegesis, Rasail al-Nur, which relate to the moral education. It discusses the background, the reason and the purpose behind Imam Bediuzzaman's approach to the issue at hand. It is also important to note down that his writing is not the result of a merely intellectual enterprise, but also the living answers to problems he has personally experienced. The thesis follows library and textual analysis to address the main problematic. Hence, it concludes that it is necessary to situate Imam Bediuzzaman's work within the context of Tauhid (Divine Unity) framework, which constitutes the background of his entire system of thought. Indeed, Imam Bediuzzaman's approach provides a scaffold for a profound understanding and interpretation of the concept of morality and its impact on one's life and social fabric.
\end{abstract}

Abstrak: Karya ini menginvestigasi pendekatan yang digunakan oleh Imam Bediuzzaman Said Nursi dalam wacana moralitas Islam, dan untuk memahami pendekatan kitab sucinya yang cemerlang terhadap nilai-nilai moral yang membuat kehidupan seseorang bermakna dan bermanfaat. Karya ini juga dimaksudkan untuk menyoroti aspek yang khas dan berbeda dari pendekatan dan metodologi yang digunakannya dalam penafsiran al-Quran, Rasā'il al-Nūr, yang dikaitkan dengan pendidikan moral. Di sini akan dibahas tentang latar belakang, alasan dan tujuan dibalik pendekatan Imam Bediuzzaman terhadap isu tersebut. Juga, penting dicatat bahwa tulisannya bukanlah hasil dari keberanian intelektual semata-mata, melainkan jiga jawaban-jawaban langsung terhadap persoalan-persoalan yang dialaminya secara pribadi. Tesis ini mengikuti analisis pustaka dan tekstual yang difokuskan pada problematika utama. Karena itu, penting utuk menempatkan karya Imam Bediuzzaman dalam konteks kerangka Tauhid, yang merupakan latar belakang dari seluruh sistem pemikirannya. Memang, pendekatan Imam Bediuzzaman menyediakan sebuah penopang untuk sebuah pemahaman dan interpretasi yang mendalam terhadap konsep moralitas dan pengaruhnya bagi kehidupan dan sistem sosial. 
Keywords: the Qur'an, Rasā'il al-Nūr, New Said, moral education, and jihād.

\section{A. Introduction}

Imam Bediuzzaman's aim with Rasā'il al-Nūr is to offer proofs and explanations of the main truths and tenets of belief taught by the Qur'an, in order to strengthen the faith of believers, along with the moral renewal, especially which after the founding of the Turkish Republic in 1923, it was worried that Muslims' belief would be spoilt by the rapid implementation of Westernizing and Secularizing reforms. ${ }^{1}$

In writing the Rasā'il al-Nūr, Imam Bediuzzaman used the Holy Qur'an as his primary source and guidance. The Qur'an addresses the intellect as well as man's other inner faculties. It directs man to consider the universe and its functioning in order to learn its true nature and purposes as the creation and thus to learn the attributes of its Single Creator and his own duties as a creature. This, then, is the method that Bediuzzaman employed in the Rasä'il al-Nür. He explained the true nature of the universe as signs of its Creator and demonstrated through clear arguments that when it is read as such all the fundamentals of belief may be proved rationally. His method was to always link the creational signs in human nature, both physical and spiritual with what those signs indicate in relation to belief. ${ }^{2}$ When this method is followed, a person attains a true belief that will be sound and firm enough to withstand any doubts that may arise in the face of the attacks of Materialism, Naturalism and atheism. Man's most fundamental need is the need for religion, the need to recognize and worship Almighty God with all His Most Beautiful Names and attributes, and to obey His laws; those manifested in the universe and those revealed through His prophets. In explaining the message of the Qur'an, brought and perfectly expounded by His final Prophet, Muhammad (PBUH), and Islam, the complete and perfected religion for mankind, Imam Bediuzzaman demonstrates in the Rasā'il al-Nūr that there is no contradiction between science and religion; rather, true progress and happiness for mankind can only be achieved in this Qur'anic way.

In his works, Imam Bediuzzaman uses certain methods to explain verses of the Qur'an in a way that it can be understood by people of various educational levels. His target is that it would be beneficial in strengthening the faith of people coming from different background. For this he has very special characteristics in writing his thematic commentary of the Qur'an. This makes the Rasā'il al-Nūr accessible to people who are not students or scholars of religion, who can still follow the exegete's argument and grasp the topics being discussed. ${ }^{3}$ 


\section{B. Brief Life of Imam Bediuzzaman Said Nursi}

Imam Bediuzzaman was born in 1876 or $1877^{4}$ in Nurs of Bitlis province in eastern Anatolia, Turkey. His life-time spanned the final decades of the Caliphate of the Ottoman Empire, its collapse and dismemberment after the First World War, and the setting up of the Republic, and then twenty five years of Republican People's Party rule, famous for the Government' s repressive anti-islamic and anti-religious policies. Until the years following the First World War, during the ten years of Democrat rule, Imam Bediuzzaman's struggles in the cause of Islam had been active and in the public domain. ${ }^{5} \mathrm{He}$ had not only taught many students and had engaged in debate and discussion with leading scholars from all over the Islamic world, but he had also commanded and led in person a volunteer regiment against the invading Russians in eastern Turkey in 1914 for nearly two years until taken prisoner6. Furthermore, up to that time he had sought to further the interests of Islam by actively engaging in public life. This period was named by Imam Bediuzzaman as the period of "Old Said". However the years that saw the transition from empire to republic also saw the transition from the "Old Said" to the "New Said". The "New Said" was characterized by his withdrawal from public life and concentration on study, prayer and thought for what was required now was a struggle of a different sort. In this period he took Qur'an as his sole guide, by means of the original method of expounding the Qur'anic truths of belief, which at the same time refuted the principles of materialist philosophy. ${ }^{7}$ In 1925 under the reign of Mustafa Kemal (Attaturk), Imam Bediuzzaman was sent into exile in western Anatolia and for the next twenty-five years, and to a lesser extent for the last ten years of his life, he suffered nothing but exile, imprisonment, harassment and persecution by the authorities. But these years of exile and isolation saw the writing of the Rasail al-Nur , the "Treat of Light" and its dissemination throughout Turkey. To quote Imam himself:

Now I see clearly that most of my life has been directed in such a way, outside my own free-will, ability, comprehension and foresight, that might produce these treatises to serve the cause of the Quran. It is as if all my life as a scholar has been spent in preliminaries to these writings, which demonstrate the miraculousness of the Quran.8

Imam Bediuzzaman wrote that his life was "a seed" out of which in His Mercy, Almighty God had created "the tree of the Rasā'il al-Nūr". Thus, when his biography was being prepared, he wanted attention to be directed towards this service to belief, rather than to his own self and personality. ${ }^{9}$ Imam Bediuzzaman realized that an essential cause of the decline of the Islamic world was the weakening of the main foundations of belief. This weakening, together 
with the constant attacks on those foundations in the 19th and 20th centuries carried out by materialists, and atheists, led him to realize that the urgent and over-riding need was to strengthen, and even to save belief. ${ }^{10}$ What was needed was to expend all efforts in the struggle against aggressive atheism and irreligion, and to answer at that level those attacks with a peaceful jihad, i.e. "Manevi Jihad " or "Jihad of the word".11 Thus in his exile, Imam Bediuzzaman wrote a body of work, the Rasā'il al-Nūr, that would explain and expound the basic tenets of belief, the truths of the Quran, to modern man. Imam Bediuzzaman died in March 23 ${ }^{\text {rd }} 1960$, or $25^{\text {th }}$ Ramadan 1379 AH in Urfa, Turkey. ${ }^{12}$

\section{The Applied Methodology of Imam Bediuzzaman in the Discourse of Moral Education}

Imam Bediuzzaman attaches the greatest importance to the effects of faith and its moral values. He calls on Muslims to assume Allah's morality; and frequently mentions divine glory and beauty, and His favors for His servants; he points out the instances of wisdom and perfection in creatures; and he draws the Muslims' attention to assuming His divine morality and to be adorned with the things it requires. In his way Imam Bediuzzaman discusses belief together with its psychological effects on life, and infuses the parts of belief with the spirit of wholeness. For this, he had certain method applied when educating himself and others on moral issues. For him, the ultimate, primary and first source of all moral teaching and reflection is Qur'an, it's teachings and values are relevant at all time. He says regarding this:

Since the Qur'an's principles and laws have come from pre-eternity, they shall go to post-eternity. They are not condemned to grow old and die like civilization's laws. They are always young and strong. ${ }^{13}$

The second source for Imam Bediuzzaman's moral discussion is the life of the prophet Muhammad (PBUH). It is important to mention these two basic sources of his writing when discussing about his method, this will enable the readers to identify with the starting point of his moral system. In regard of Imam Bediuzzaman's method in Moral discourse, his basic methodology is to study Qur'an and apply its moral implications and insights in the current situations, he also comes with some Prophetic traditions to strengthen his argument. Some examples of this basic methodology are as follows:

1- In the discussion about the importance of supplication

In this regard, Imam Bediuzzaman first come with the Qur'anic verse, which says:

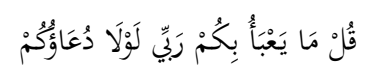


Say: My Sustainer would not concern Himself with you but for your supplication, ${ }^{14}$

which has the meaning of: What importance would you have if you did not offer Me supplications? He also commands:

"Call upon Me and I will answer you."

In this context, Imam Bediuzzaman differentiates between supplications being accepted and it is being answered. To him, to answer is one thing, to accept is something quite different. Every supplication is answered, but it is being accepted and exactly what was sought being given is dependent on Almighty God's wisdom. Imam Bediuzzaman gives the example, if a sick child calls the doctor, and asks him to be given the certain medicine. The doctor will either give him exactly what he asks for, or something better and more beneficial for him, or knowing that medicine is harmful for his illness, he will give him nothing.

Thus, since Almighty God is all-present and all-seeing, He responds to the supplications of His servants. Through His presence and response, He transforms the desolation of loneliness and solitude into familiarity. But He does this, not in accordance with man's capricious and importunate demands, but in accordance with the requirements of dominical wisdom; He gives either what is sought, or what is better than it, or He gives nothing at all, knowing that nothing is the best for His servant.

Further Imam Bediuzzaman says that a man despite his boundless impotence, and suffers from endless needs and has innumerable desires, despite his boundless poverty, after belief, his fundamental innate duty is supplication. As for supplication, it is the basis of worship of God and servitude to Him. In order to secure a desire or wish he cannot obtain, a child will either cry or ask for it, that is, he will supplicate through the tongue of his impotence either actively or verbally, and will be successful in securing it. In the same way, man is like a delicate, petted child in the world of living creatures. He has to either weep at the Court of the Most Merciful and Compassionate One through his weakness and impotence, or supplicate through his poverty and need, so that the things he wants may be made subject to him, or he may offer thanks for their being made so. Belief necessitates supplication as a certain means of securing needs, and both human nature has an intense desire for it.

Imam Bediuzzaman also argues that supplication is one of the need of a human since it is a form of either the following three:

1- It is a form of worship and recognition of man's servitude to God.

2- It is the fruits of this world pertain to the hereafter. 
3- It is the aims pertaining to this world are the times of a particular sort of supplication and worship.

From here we see that Imam Bediuzzaman explains in detail based on the verses mentioned, the morality reflected from them.

Furthermore, to analyze Imam Bediuzzaman's method comprehensively, one would require examination of the historical and psychological background of the people whom he addressed at that time. Some examples of his applied methods which are significant in his Moral discussion are:

1- Method of Reflective Thought

2- Method of Allegorical Comparisons

3- Method of Directing and Advising

4- Method of good exemplary life

5- Method of retelling the past stories

6- Method of Hope and Fear

7- Method of wisdom/poetic verses

The details of the above mentioned methodologies are as follow:

1- Reflective Thought

Imam Bediuzzaman states that the Risale-i Nur is based on four principles, are: impotence, poverty/want, compassion and reflective thought.

Reflective thought or tafakkur is seeing Divine Wisdom in its creation and acknowledging how beautiful the cosmos has been created. ${ }^{15}$ In this regard, he says:

The ways leading to Almighty God are truly numerous. While all true ways are taken from the Qur'an, some are shorter, safer, and more general than others. Of these ways taken from the Qur'an is that of impotence, poverty, compassion, and reflection, from which, with my defective understanding, I have benefited. ${ }^{16}$

The reflective thought takes the most important principle of the Rasä'il al$N \bar{u} r$. The other three are the result of it. This principle was at the same time the most important factor shaping Bediuzzaman's life. First of all, what can be seen throughout his works is that he sees the universe as a book. He uses this metaphor very often and one has to keep this constantly in mind while reading the Rasä'il al-Nūr. The universe needs to be "read" and understood as one of the three evidences of God's existence, the other two are the Qur'an and the Messenger sent by God. Through reflective thought (tefekkur), which is based on the divine names and a form of deductive reasoning, one observes the universe and tries to read the divine marks on every single creation. ${ }^{17}$

The spiritual side of Imam Bediuzzaman was shaped by the combination of Tafakkur with the way of poverty, impotence and compassion. ${ }^{18}$ The way of reflective thought or tafakkur was one of the most essential and most important elements of the Rasā'il al-Nūr, which according to Sukran Vahide it is the 
necessary complement of 'the book of the universe'. ${ }^{19}$ In the preface to the Twenty-Ninth Flash, Imam Bediuzzaman expresses this idea, in which he calls it as a 'Tefekkurname' or 'piece on which to reflect':

Thirteen years ago, my heart combined with my mind and urged me to the way of reflective thought which the Qur'an of Miraculous Exposition commands with such verses as, That you may consider. $20 *$ Perchance they may reflect. ${ }^{21} *$ Do they not reflect in their own minds, did God create the heavens and the earth?22* There are signs for those who consider. ${ }^{23}$ The Hadith the meaning of which is "An hour's reflective thought is better than a year's [voluntary] worship" 24 states that on occasion an hour's reflection may be equivalent to a year's worship. It also offers powerful encouragement for reflective thought. For myself, in order to preserve the extensive lights and lengthy truths which appeared to my mind and heart during the thirteen years I have followed this way, I recorded a number of phrases by way of indications, not to point out those lights, but to indicate their existence, facilitate reflection, and preserve the order. I used to recite the phrases to myself verbally in varying Arabic terms when I embarked on the reflection. On being repeated thousands of times over this long period, neither did I become wearied, nor did the pleasure they afforded diminish, nor the spirit's need of them lessen. Because, since the reflection all consisted of flashes from Qur'anic verses, the qualities of not causing weariness and preserving their sweetness, which are qualities of the verses, were represented in the mirror of that reflective thought. I realized recently that the powerful source of life and brilliant lights in the various parts of the Rasail al-Nur are flashes of those sequences of thought. 25

As human passes through different steps of life, and travels through the universe questioning each of their testimony to the Divine existence and Unity, his belief gains universality and strength with each degree, and passes the belief from imitative to certain, ${ }^{26}$ and this can only be gained through the way of tafakkur.

2- Method of Allegorical Comparisons ${ }^{27}$

Imam Bediuzzaman explains that great things are achieved through the use of analogies and allegories: "imagination is compelled to submit to thought, the hidden is made present, the abstract made tangible, and the meaning made palpable." 28 Imam Bediuzzaman explains this method as follows:

1. The stories or parables in the Words... are sorts of allusions.

2. The truths at the end of the stories are extremely correct, extremely true and conformable to reality; they are the allusive meanings of the stories.

3. Their essential meanings are comparisons that bring distant objects close like a telescope and however they may be it does not damage their veracity and truthfulness. 
4. All those stories are comparisons or parables. Purely to enable people in general to understand, what is properly communicated without words is put into words, and immaterial and abstract matters are represented in material form.

5. Just as in many places in the Risale, Nursi uses this way of allegory also for the "ten proofs of the resurrection of the dead that are based on such matters as the order in the universe, the wisdom and purposes followed in beings, and the absence of futility and absence of waste."

This approach of allegorical comparisons is essentially Qur'anic, since the Qur'an uses a similar way of communication, the use of analogies and allegories are important part of the Qur'an's methodology. Some of where analogies, parables and similitude are mentioned in Qur'an are:

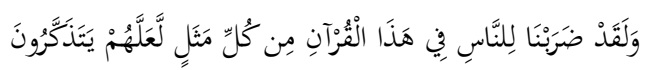

"We have put forth for men, in this Qur'an every kind of parable, in order that they may receive admonition." 29

Imam Bediuzzaman adopts an approach that resorts to the use of metaphor and allegory in order to reveal the inner significance of things. This is the method of exposition, it results in a greater degree of certainty than the categorical proofs of logic. ${ }^{30}$ It is a method founded on the Qur'anic distinction between the outer appearances of the verses of the Qur'an on the one hand, and the inner reality underlying them. ${ }^{31}$

According to Smith, the widespread popularity and continuing success of the Rasā'il al-Nūr, may in part be due to the liberal use of the allegorical comparisons, that attract and hold the attention, making truths, easily comprehensible. For Nursi, images and metaphors are basic teaching tools as for most of the religious leaders throughout the ages. As Smith states,

Nursi's purposes are homiletic and didactic rather than descriptive, offered for one primary purpose: to contrast the ultimate experiences of existence of the faithful with those who are without faith. ${ }^{32}$

Also, she writes,

One of the reasons that he has endured through the 20th century and into the $21^{\text {st }}$ as a highly revered interpreter of Islam and the Qur'an is his ability to speak, through his writing, in words that are ,straightforward yet rich in interpretive symbolism. The reader feels Nursi's passion, comprehends his instruction, and experiences his understanding of truth through his graphic and sometimes even startling use of words and images. In the extended Rasail al-Nur collection one finds frequent use of what are called temsil or allegorical comparisons, which he himself admits to using so as to facilitate understanding and specifically to help illustrate the truths of the Qur'an. ${ }^{33}$

Some of examples related to Moral Educating by using this method are: 
1- He likens one who forgets to work for hereafter life to an ostrich. This person will not be saved from the torture of the hellfire.

And what are the goods of this world but the goods of deception?

[A slap for the heedless and a warning lesson]

0 my wretched soul sunk in heedlessness, which sees this life as sweet, has forgotten the hereafter, and seeks only this world! Do you know what you resemble? An ostrich! It sees the hunter, but cannot fly, so sticks it head in the sand so the hunter will not see it. Its bulky body remains in the open, and the hunter sees it. Only, its eyes are closed in the sand and it cannot see him. ${ }^{34}$

2- He likens one's heart, soul identity and nature to a mirror which reflects sunlight.

Imam Bediuzzaman says regarding this:

There are certain foolish people who because they do not recognize the sun, if they see it in a mirror, start to love the mirror. With intense emotion they try to preserve the mirror so that the sun within it will not be lost. Whenever the foolish person realizes that the sun does not die on the mirror's dying and is not lost on its being broken, he turns all his love to the sun in the sky. He understands then that the sun seen in the mirror is not dependent on the mirror, nor does its continued existence depend on it. It is rather the sun which holds the mirror, supplying its shining light. The sun's continuance is not dependent on the mirror, rather the continuance of the mirror's living brilliance is dependent on the sun's manifestation.

0 man! Your heart, identity, and nature are a mirror. The intense love of immortality in your nature and heart should be not for the mirror, nor for your heart and nature, but for the manifestation of the Enduring One of Glory, Whose manifestation is reflected in the mirror according to the mirror's capacity. However, due to stupidity that love of yours is directed to other places. ${ }^{35}$

Imam Bediuzzaman talks of love in many sections of his work, emphasizing that we often misuse the love that we are given the ability to experience. He argues that one should love the One who is truly deserving of that love and that is God. One should not give his love to the reflection in the mirror, forgetting that the reflection has a source. Imam Bediuzzaman expresses this misdirected love as follows:

0 my heart! The most stupid person is he who does not recognize the sun while he sees its image in a mirror, and loves only the mirror and tries to preserve it passionately with the aim of holding on to the sun permanently. ${ }^{36}$

The key to loving in the correct manner is by realizing that the mirror's reflection depends on the sun's manifestation. When the mirror dies the sun within it will not be lost. Imam Bediuzzaman tells the readers that the intense 
love should not be for one's own soul which is like mirror which is simply the reflection of God's manifestation, but it should be for God.

Love for God is the essence of worship; it contributes quite significantly to the spiritual well-being of man. With a true love which seeks no pretex for its beloved and stems from the illuminative knowledge of God, the journey of Muslim as a traveler to God, will be undergone easily, all sorts of hardships that might hinder the journey would easily be eliminated. ${ }^{37}$

There are many other examples in regard of this method. Rasā'il al-Nūr are comprised of many analogies and allegories which help one to comprehend the spiritual concepts which would otherwise be very difficult to understand. Imam Bediuzzaman follows the method of the Qur'an in using analogies and allegories. As Zuleyha Keskin writes that the use of analogies is particularly important in today's time where science has separated from religion making it difficult for people to accept the existence of anything metaphysical. ${ }^{38}$

\section{3- Method of Directing and Advising}

Imam Bediuzzaman uses the method of directing and advising especially when he was asked by some students or other people about certain matters which require advice, so most of the discussion is carried out in the form of question-answer. Some examples of this method are as follows:

1. One day a number of bright youths came to him, seeking an effective deterrent in order to guard themselves against the dangers arising from life, youth, and the lusts of the soul. Imam Bediuzzaman said to these youths, which summarized as follows:

- Youth will definitely leave you, and if you do not remain within the bounds of the licit, it will be lost, and rather than its pleasures, it will bring you calamities and suffering in this world, in the grave, and in the hereafter.

- You must spend the bounty of your youth through Islamic training as thanks honorably, in uprightness and obedience, so that it will in effect remain perpetually and will be the cause of gaining eternal youth.

- Life without belief will produce pains, sorrows and grief far exceeding the superficial, fleeting enjoyment it brings.

- Contrary to the animals, man possesses a mind and he thinks, he is connected to both the present time, and to the past and the future. He can obtain both pain and pleasure from them.

- From the point of view of the pleasure of life, unbelief can drive man to a level a hundred time lower than the animals.

- From the point of view of their misguidance, all the time and universes of the past are non-existent, are dead. So their intellects, which connect them to the past and the future, produce darkness, blackness for them. Due to 
their lack of belief, the future is also non-existent. Furthermore, because they think, the eternal separations resulting from this non-existence continuously produce darkness for their lives.

- If belief gives life to life, then through the light of belief, both the past and the future are illuminated and find existence. Like present time, it produces elevated, spiritual pleasures and lights of existence for the spirit and heart-in respect of belief.

- If you want the pleasure and enjoyment of life, give life to your life through belief, and adorn it with religious duties, and preserve it by abstaining from sins. ${ }^{39}$

2. Some of his students came to him and asked him this question: "What is the purpose and aim of the saying,

God is with those who patiently persevere?" 40

He answers this question with the following advices:

- As required by His Name of All-Wise, Almighty God placed in all things an arrangement like the steps of stairs.

- An impatient man does not act with slow deliberation, and so either skips some of the steps and falls, or leaves some deficient; he cannot mount to the roof of his goal.

- Thus, greed is the cause of loss.

- Patience however is the key to all difficulties, and the saying, "The greedy is subject to disappointment and loss," and the Hadith, "Patience is the key to happiness," 41 which means that Almighty God's grace and favour are with the patient.

- Patience is threefold:

i. The First is to patiently persevere in refraining from sin; this patience is

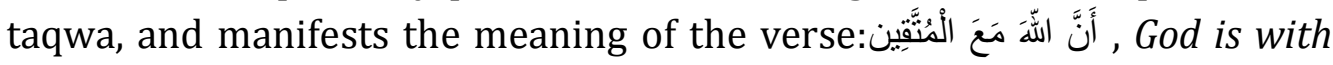
those who fear Him and restrain themselves. ${ }^{42}$

ii. The Second is patience in the face of calamity; this to place one's trust in God and to submit to Him. It is to be honoured by the manifestation of

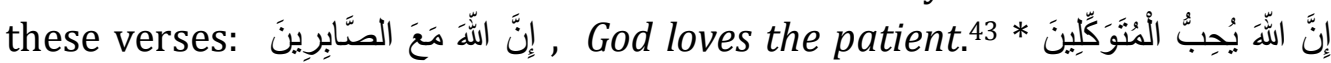
God loves those who put their trust in Him. ${ }^{44}$ As for impatience, it amounts to complaining about God, and to criticizing His actions, accusing His mercy, and not liking His wisdom. For sure, man is weak and powerless, and weeps complainingly at the blows of misfortune, but his complaint must be to Him, not about Him. It should be like the words of Jacob (Upon whom be peace): He said: إنَّمَا أَثَنْكُ بَتِّي وَحُزْنِي إِلَى اللّه , I only complain of my distraction and anguish to God. ${ }^{45}$ That is to say, he should complain to God, not lament saying: "What have I done that this should have happened to 
me?" as though complaining to other human beings about God; to excite the sympathy of impotent humans is harmful and meaningless.

iii. The Third Sort of Patience is patient perseverance in worship, which raises a person to the station of being beloved of God. It urges a person towards perfect worship of God and servitude of Him, which is the most elevated station. ${ }^{46}$

In other place, Imam Bediuzzaman stresses on the above mentioned discussion by addressing his own soul: 47

My impatient soul! You are charged with being patient in three respects. One is patience in worship. Another is patience in refraining from sin. And a third is patience in the face of disaster. ${ }^{48}$

\section{4-Method of good exemplary life}

Imam Bediuzzaman's undergoes the exemplary life. He has been attempting his best to follow the teachings and the practices of the best model, the prophet Muhammad (PBUH). He is grateful for all what happens to him. He stresses the theme of mercy in his writings. He exposes how Divine mercy is shown in the harmonious ordering of the universe which fulfills the needs of all creatures especially man. For this each person has to show positive morality towards Allah and humanity. With His mercy, Allah provides all living beings in this world with utmost order and regularity, with particular senses for various uses and benefits. He also teaches them how to fulfill their needs. This demonstrates that their Compassionate Maker knows them, sees them and hears them. ${ }^{49}$ Allah provides for humans every sort of gift, and they are endowed with appetites, needs, feelings and sense so that with them they can derive the pleasure from the Divine's gift. The existence of the tiny fruit is also showing the product of mercy and generosity of Allah, how He revolves the earth, causes the seasons and thus brings the fruits of the season which are reached and enjoyed by humans. ${ }^{50}$

Imam Bediuzzaman believes that everything created in this universe is due to His mercy and on special purposes, nothing happens by chance and meaningless. Even the creation of evil, feeling of fear, death and other undesirable things and events are good in their results. In reality, apparent harms, disasters and calamities are not misfortunes. They are created for many everlasting and beneficial results. They are created to be means of purification and spiritual progress, or atonement for sin, warnings and favors of the Merciful Lord to prevent man from falling into dissipation, remind him of his human helplessness and to prepare him for the eternal life. ${ }^{51}$ In this regard Allah says:

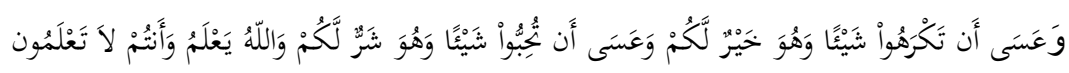


"It may well be that you hate a thing the while it is good for you, and it may well be that you love a thing the while it is bad for you, and Allah knows whereas you do not know."52

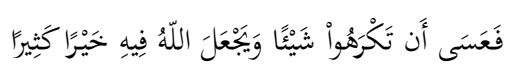

"It may well be that you dislike something which Allah might yet make a source of abundant good." 53

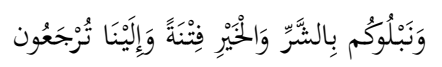

"And We test you all through the bad and the good by way of trial; and unto Us you shall be brought back." 54

The following example is Imam Bediuzzaman's gratitude in whatever the situation he is, which leads him to gaining self-comfort. He also offers thanks to the Most Merciful of the Merciful that He has transformed the various 'misfortunes' against him into various forms of mercy. When he was exiled by the authority, the All-Compassionate and Wise Creator turned the exile into mercy; He transformed the solitude on the mountain, which was unsafe and exposed to factors that would harm sincerity, into a retreat in the safe and sincere mountains of Barla. While a prisoner-of-war in Russia he made the intention to withdraw into a cave towards the end of his life and offered supplications for that purpose. The Most Merciful of the Merciful made Barla the cave and bestowed the benefits of a cave, but He did not burden the difficulties and troubles of a cave on his weak being. The All-Compassionate Creator transformed that isolation into a vast mercy for him. It left his mind clear and was the means of his receiving the effulgence of the All-Wise Qur'an as it is, free of all malice and ill-will. Later he elaborates this event as follows:

My All-Compassionate Sustainer and All-Wise Creator transformed that tyranny into mercy, for He transformed it into a desirable solitude and acceptable retreat for me during these Three Months, which will gain a spiritual life of ninety years. All thanks be to God for all conditions, my condition and comfort is thus..... 55

He also says:

It has now become absolutely clear in my view that most of my life has been directed in such a way, outside my own will, ability, comprehension, and foresight, that it might produce these treatises to serve the All-Wise Qur'an. It is as if all my life as a scholar had been spent in preparation and preliminaries, the result of which was the exposition of the Qur'an's miraculousness through the Words. I have no doubt even that these seven years of exile, and the situation imposed on me whereby I have been isolated for no reason and against my wish, living a solitary life in a village in a way opposed to my temperament, and my feeling disgust at and abandoning many of the ties and rules of social life to which I had long grown accustomed, was in order to make me carry out this duty to 
serve the Qur'an directly and in purely sincere fashion I am of the opinion that the ill-treatment was very often visited on me by a hand of favour under the veil of unjust oppression, compassionately, in order to focus and restrict my thought on the mysteries of the Qur'an and not allow my mind to be distracted. And being prevented from studying all other books, despite formerly having great desire to study, I felt an aloofness towards them in my spirit. I understood that what had made me give up studying, which would have been a solace and familiar in my exile, was in order for the verses of the Qur'an to be my absolute master directly. ${ }^{56}$

It can be seen from the above mentioned words that Imam Bediuzzaman's life followed a course entirely outside his own will and consciousness, being directed in such a way he would to serve the Qur'an by means of the Rasail alNur.57.

Other example that we can learn from the life he lives is his frugality. He is grateful and thankful to Almighty God for whatever the portion he receives, and he refuses to take any kind of financial assistance including zakat and charity. This leads him to gain self-respect. Imam Bediuzzaman starts with the following Hadith:

"He who is thrifty will not have family difficulties as regards livelihood,"58 the frugal and economical person will not suffer undue trouble and hardship in supporting his family. There are countless proofs that the consequence of frugality is plenty and good living. For instance, I have seen myself and I can say according to the testimony of those who have befriended and assisted me that through being frugal, I have sometimes seen a tenfold increase, and so have my friends. Even, nine years ago, a number of the tribal leaders who were exiled to Burdur together with me did their best to make me accept their zakat so that would not suffer privation and humiliation through lack of money. I said to those rich leaders: "Although I have very little money, I am frugal and economical and I am accustomed to being content with little. I am richer than you." I refused their repeated and insistent offers. It is worth noting that two years later some of those who had offered me their zakat were in debt because they had not been frugal. Thanks be to God, seven years on from that, through the plenty resulting from frugality that small amount of money was still sufficient for me; it did not degrade me, nor compel me to present my needs to the people, nor make me deviate from my way of self sufficiency and being independent of people, which is one of the principles of my life. 59

Sukran Vahide ${ }^{60}$ mentions in Imam Bediuzzaman's biography that from his very early years of medrese life, as she says:

That he began to practice the self-sufficiency that was to be his mark throughout his life, even when he extremely needed. The young Said displayed complete 
independence, accepting nothing from others, even gifts, unless he was able to give something in return, and this is contrary to normal practice among the medrese student in Anatolia, who had their daily needs met by the local villagers or by zakÉt. Similarly when he later had his own students, he did not permit them to accept the charity. This was to impress upon them the need to work for God's pleasure alone. He remained detached from the world and its vanities, owning virtually nothing by way of property and possessions.

Imam Bediuzzaman agrees that education is crucial, his method is to emphasize the centering the individual in a life of faith and commitment; it is an inculcation of a disciplined Islamic life focused on the consciousness of God, a program for moral rearmament. 61

\section{5-Method of retelling the past stories}

One of the way how Imam Bediuzzaman conveys his messages on morality is by telling some stories mentioned in Qur'an. The objectives of telling stories in Qur'an have been mentioned in some verses, below are some of them:

1- For people to reflect.

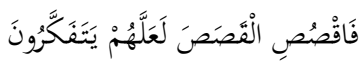

That is the similitude of those who reject Our signs; So relate the story; perchance they may reflect. 62

2- To be a lesson for people to learn, and to be a guidance and mercy for believer.

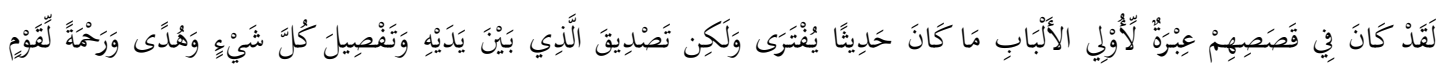

There is, in their stories, instruction for men endued with understanding. It is not a tale invented, but a confirmation of what went before it,- a detailed exposition of all things, and a guide and a mercy to any such as believe.63

In this regard, Imam Bediuzzaman says:

I understand from the masterly signs and indications of the Qur'an's Miraculousness in the stories of the prophets and their miracles, that it is encouraging mankind to attain similar achievements. It is as though with these stories, the Qur'an is pointing the finger at the main lines and final results in the future of mankind's efforts to progress, for the future is built on the foundations of the past, while the past is the mirror of the future. 64

He also says:

The reasons for my writing these treatises in the form of metaphors, comparisons and stories are to facilitate comprehension and to show how rational, appropriate, well-founded and coherent are the truths of Islam. The meaning of the stories is contained in the truths that conclude them; each story is like an allusion pointing to its concluding truth. Therefore, they are not mere fictitious tales, but veritable truths. ${ }^{65}$ 
Imam Bediuzzaman gives great importance in the use of telling stories in his writings, it can be seen in the beginning of the First, Second and Third Words for example:

[Brother! You wanted a few words of advice from me, so listen to a few truths included in eight short stories, which since you are a soldier, are in the form of comparisons of a military nature. 66

If you want to understand what great happiness and bounty, what great pleasure and ease are to be found in belief in God, listen to this story which is in the form of a comparison $(. . .)^{67}$

If you want to understand what great profit and happiness lie in worship, and what great loss and ruin lie in vice and dissipation listen to and take heed of the following story which is in the form of a comparison $(\ldots)^{68}$

Some examples of his applied method in this kind which are taken from the Qur'anic stories are as follows:

1. Giving up egotism and arrogance

In Rasā'il al-Nūr, Imam Bediuzzaman emphasizes that without God's help, humans are not able to achieve anything. All what have been received by them in any means, from intelligence, strength, beauty and many more, are from God alone. For this, there is no reason that human boast of their individual qualities without mentioning their Creator Who has bestowed all these bounties and mandated their proper use. Imam Bediuzzaman points to the Qur'anic example of Qarun, who had been so ungrateful with all the riches given to him by God, when he boasted: "I have been given it on account of the knowledge I have,"69 that is, "I gained this through my own knowledge and my own power" in a way that demonstrates ingratitude and denies his Creator's mercy and accuses His wisdom, he will of course deserve a punishing blow. The Divine retribution that consequently was visited on him was on account of his unseemly arrogance and ingratitude. For this example mentioned in Qur'an, imam Bediuzzaman warns the readers:

"O man! Since the reality of the matter is thus, give up egotism and arrogance. With the tongue of seeking help proclaim your impotence and weakness at the Divine Court, and with the tongue of entreaty and supplication, your poverty and need. Show that you are His slave. Say: God is enough for us, for He is the Best Disposer of Affairs, 70 and rise in degree. ${ }^{71}$

\section{Being Patient}

In the discussion of morality related to being patient, imam Bediuzzaman gives the readers the example of the story of Prophet Job or Ayub (Peace be upon him). He was regarded as the champion of patience. He was tested by Allah with the sickness and suffered for a long time, and yet he was patient and never complained even a bit. He started to call upon his Sustainer when he felt 
that the worms generated by his wounds penetrated to his heart and his tongue, the seat of the remembrance and knowledge of God, he feared that his duty of worship would suffer, and so he said in supplication not for the sake of his own comfort, but for the sake of his worship of God, he supplicated:

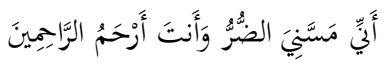

"Verily harm has afflicted me, and You are the Most Merciful of the Merciful."72" Imam Bediuzzaman interprets his supplication as follows:

"O Lord! Harm has afflicted me; my remembrance of You with my tongue and my worship of You with my heart will suffer."73

For this, God Almighty accepted this pure sincere, disinterested and devout supplication in the most miraculous fashion. He granted to Prophet Ayub perfect good health and made manifest in him all kinds of compassion.

6-Method of Hope and Fear

Some examples given below are:

Gratitude and Patience

Imam Bediuzzaman gives the spiritual support to his disciples who are destructed by being imprisoned for the cause of spreading Islam and the truth, for those who realize that this is another type of test from Allah, will spend each and every moment for worship, so they must offer thanks, for they know that there is hope of Allah's forgiveness when they are patient and grateful. He says:

My Dear, Loyal Brothers!

I shall explain in three 'Points' an effective solace for those who are experiencing the calamity of prison, and for those who kindly help them and faithfully supervise their food, which comes from outside. First Point: Each day spent in prison may gain as much as ten days' worship, and, with regards to their fruits, may transform those transient hours into enduring hours, and through five or ten years' punishment may be the means of saving a person from millions of years of eternal imprisonment. For the believers, the condition for gaining this most significant and valuable advantage is to perform the obligatory prayers, repent for the sins that were the cause of their imprisonment, and offer thanks in patience. ${ }^{74}$

The example shown above is about giving hope, which is meant to encourage people of doing such deeds so that they can gain success, reward and forgiveness.

\section{6-Method of wisdom/poetic verses}

This method is very popular in the writing of Rasail al-Nur, Imam Bediuzzaman explains this as follows:

The truth and perfections in in the Word are not mine: they are the Qur'an's and they have issued from the Qur'an. 
He also uses this method when it comes to the discussion of morality. Serif Mardin sees Said Nursi's idiom as a synthesis between the old and the new, he quoted:

"A methodolical point which is of key interest for an understanding of the way in which Said Nursi's idiom worked is that morality as command depends on discursive resources whereas morality as means of finding an integration with the created in the individuals by this symbols. Said Nursi's discourse contains resources of both types. This is where he had superiority over the more orthodox Islamic reformist." 75

The poetic style of Risalei Nur conveys the message in a way that the readers can grab its meaning and feel it. There are many examples of this kind found in Risalei Nur, but some examples only will be displayed here, as follows:

\section{About Misfortunes and Calamities}

Cry not out at misfortune, $\mathrm{O}$ wretch, come, trust in God!

For know that crying out compounds the misfortune and is a great error.

Find misfortune's Sender, and know it is a gift within gift, and pleasure.

So leave crying out and offer thanks; like the nightingale, smile through your tears!

If you find Him not, know the world is all pain within pain, transience and loss.

So why lament at a small misfortune while upon you is a world full of woe?

Come trust in God!

Trust in God! Laugh in misfortune's face; it too will laugh.

As it laughs, it will diminish; it will be changed and transformed.

Know, $\mathrm{O}$ arrogant one, happiness in this world is in abandoning it.

To know God is enough. Abandon the world; all things will be for you.

To be arrogant is total loss; whatever you do, all things will be against you.

So both states demand abandoning the world here.

Abandoning the world is to regard it as God's property, with His permission, in His Name...

If you want to do trade, it lies in making this fleeting life eternal.

If you seek yourself, it is both rotten and without foundation.

If you seek the world outside, the stamp of ephemerality is upon it.

That means there is no value in taking it; the goods in this market are all rotten.

So pass on...the sound goods are all lined up beyond it.

2. His advice on various matters

- If you want a friend, God is sufficient. Yes, if He is the friend, everything is a friend.

- If you want companions, the Qur'an is sufficient. Indeed, for in the imagination one meets with the prophets and angels in it, observes the events in which they were involved, and becomes familiar with them. 
- If you want possessions, contentment is sufficient. Yes, one who is content is frugal; and one who is frugal, finds the blessing of plenty.

- If you want an enemy, the soul is sufficient. Yes, one who fancies himself is visited with calamities and meets with difficulties. Whereas one who is not fond of himself, finds happiness, and receives mercy.

- If you want advice, death is sufficient. Yes, one who thinks of death is saved from love of this world, and works in earnest for the hereafter. ${ }^{76}$

\section{Conclusion}

Imam Bediuzzaman Said Nursi was a prominent Islamic teacher and scholar who, in the last decades of the Ottoman Empire, joined in the desperate debates over how to save the Empire and restore its power. He put forward many original solutions, most of which were in the field of education. He was a firm believer in science and modernization, but in the light of the Qur'an. Imam Bediuzzaman seeks to show that man's true happiness and progress are to be found through the teachings of the Qur'an. For him, it was the Qur'an and Islam that could provide the principles for true human progress and his main approaches were primarily concerned with ethics and morality. That is to say, in his view moral renewal was another essential dimension of the struggle to achieve the progress and unity of the Islamic world. Besides educating in the broadest sense and raising religious consciousness with the Rasail al-Nur, Imam Bediuzzaman hoped to effect moral renewal and the strengthening of society from the bottom up. For this, he attempts to adopt the different kinds of methodologies applied in the Qur'an. In regard of his method in moral discourse, his basic methodology is to study Qur'an and apply its moral implications and insights in the current situations, he also comes with some Prophetic traditions to strengthen his argument. This is the attempt to facilitate him in obtaining his aim in writing Rasail al-Nur, which is to offer proofs and explanations of the main truths and tenets of belief taught by the Qur'an, in order to strengthen the faith of believers along with the moral refinement.

\section{BIBLIOGRAPHY}

Alatas, Syed Farid, The Social Theology of Bediuzzaman Said Nursi and the Critique of Modern Civilization in Knowledge, Faith, Morality and the Future of Humanity, Ninth International Symposium on Bediuzzaman Said Nursi, $3^{\text {rd }-5^{\text {th }} \text { October 2010, Istanbul: Istanbul Ofset, } 2010 .}$

Haddad, Yvonne Yazbeck, Ghurbah as Paradigm for Muslim Life: a Risalei Nur, in The Muslim World, Special Issue: Said Nursi and the Turkish Experience, 89th 
Volume, number 3-4, The Duncan Black Macdonald Center at Harford Seminary, July-October 1999.

Jane I Smith, "Similes and Metaphors of Life and Death in the Writings of Bediuzzaman Said Nursi," in Fifth International Symposium on Bediuzzaman Said Nursi the Qur'anic View of Man, According to the Rasail al-Nur, Sozler Nesriyat, 2000.

Keskin, Zuleyha, Overcoming Challenges In understanding Metaphysical and Spiritual Concepts, in Knowledge, Faith, Morality and the Future of Humanity, Ninth International Symposium on Bediuzzaman Said Nursi, $3^{\text {rd }}$ $5^{\text {th }}$ October 2010, Istanbul: Istanbul Ofset, 2010.

Kuspinar, Bilal, The Chief Characteristics of Spirituality in Said Nursi's Religious Thought, in Spiritual Dimensions of Bediuzzaman Said Nursi's Rasail al-Nur, edited by Ibrahim M Abu Rabi, New York: State University of New York Press, Albany, USA, 2008.

Markham, Ian, and Suendam Birinci Pirim, An Introduction To Said Nursi, Life, Thought and Writings, UK: Ashgate Publishing Limited, 2011.

Marzuqi, Jamal, Moral Philosophy in the Qur'an from the Viewpoint of the Rasail al-Nur, in The Qur'anic View of Man, According to the Rasail al-Nur, Fifth International Symposium on Bediuzzaman Said Nursi, 24 $4^{\text {th }}-26^{\text {th }}$ September, 2000, Sozler Publication, Istanbul 2002.

Nursi, Bediuzzaman Said, 'The Words', Translated from Turkish by Sukran Vahide, Istanbul, Turkey: Sozler Publication, 2008.

Nursi, Bediuzzaman Said.'The Flashes', Translated from Turkish by Sukran Vahide, Istanbul, Turkey: Reyhan Ofset, Sozler Publication, 2004.

Nursi, Bediuzzaman Said.'The Rays', Translated from Turkish by Sukran Vahide, Istanbul, Turkey: Reyhan Ofset, Sozler Publication, 2006.

Nursi, Bediuzzaman Said.'The Letters', Translated from Turkish by Sukran Vahide, Istanbul, Turkey: Reyhan Ofset, Sozler Publication, 2005.

Nursi, Bediuzzaman Said 'The Signs of Miraculousness', Translated from Turkish by Sukran Vahide, Istanbul, Turkey: Reyhan Ofset, Sozler Publication, 2007.

Suyūtī, Jalāl al-Dīn Abd al-Raḥmān b. Abī Bakr, al-Fatḥ al-Kabīr, Juz 2, Beirut: Dār al-Fikr, 1423 H/2003.

Vahide, Sukran, 'The Life and Times of Bediuzzaman Said Nursi', in The Muslim World, Special Issue: Said Nursi and the Turkish Experience, 89th Volume, 
number 3-4, The Duncan Black Macdonald Center at Harford Seminary, July-October 1999.

Vahide, Sukran, A Chronology of Said Nursi's Life, in Islam at the Cross Road, edited and with introduction by Ibrahim Abu Rabi, New York: State University York New York Press, 2003.

Vahide, Sukran, About the Rasail al-Nur, The Words and their Author, in the Words, Sozler Publication, 2008.

Vahide, Sukran, Proof of the Resurrection of the Dead: $S$ aid Nursi's Approach, published in Theodicy and Justice in Modern Islamic Thought, The Case of Said Nursi, edited by Ibrahim M. Abu Rabi, UK: Ashgate Publication, 2009.

Vahide, Sukran, The Author of the Rasail al-Nur Bediuzzaman Said Nursi, Istanbul Turkey: Reyhan Ofset, 2004.

Vahide, Sukran, The Life and Times of Bediuzzaman Said Nursi, The Muslim World, Vol LXXXIX, No 3-4, 1999.

Zuhayli, Wahba, Man in the Qur'an from the Viewpoint of the Rasail al-Nur, Fifth International Symposium.

\section{Endnotes}

${ }^{1}$ Sukran Vahide, Proof of the Resurrection of the Dead: Said Nursi's Approach, published in Theodicy and Justice in Modern Islamic Thought, The Case of Said Nursi, edited by Ibrahim M. Abu Rabi, UK: Ashgate Publication, 2009, p. 41.

2Wahba al-Zuhayli, Man in the Qur'an from the Viewpoint of the Rasail al-Nur, Fifth International Symposium, p. 37.

3Ian Markham and Suendam Birinci Pirim, An Introduction To Said Nursi, Life, Thought and Writings, UK: Ashgate Publishing Limited, 2011, p. 18.

${ }^{4}$ In this regard, Sukran Vahide quoted that there are some discrepancies between the dates given for his birth day in the available sources but the majority give it as 1293 Rumi. See: Sukran Vahide, The Life and Times of Bediuzzaman Said Nursi, The Muslim World, Vol LXXXIX, No 3-4, 1999, p. 208.

5Sukran Vahide, About the Rasail al-Nur, The Words and their Author, in the Words, Sozler Publication, 2008, p. 803.

'Sukran Vahide, A Chronology of Said Nursi's Life, in Islam at the Cross Road, edited and with introduction by Ibrahim Abu Rabi, New York: State University York New York Press, 2003, p. xix.

7 Ibid.

${ }^{8}$ Said Nursi, The Letters, p. 441.

${ }^{9}$ Sukran Vahide, The Author of the Rasail al-Nur Bediuzzaman Said Nursi, Istanbul Turkey: Reyhan Ofset, 2004, p. x.

${ }^{10}$ Fred A.Reed, Anatolia Junction, Canada: Talonbooks, 1999, p. 226.

${ }^{11}$ Sukran Vahide, The Author, p. 352.

${ }^{12} \mathrm{Ibid}$, p. 373

${ }^{13}$ Said Nursi, The Words, p. 421.

${ }^{14}$ QS. al-Furqān [25]: 77.

${ }^{15}$ Said Nursi, Supreme Signs, 7th Rays, p. 123.

${ }^{16}$ Said Nursi, The Words, p. 491.

${ }^{17}$ Said Nursi, The Rays, (The Seventh Ray), p.123. 
${ }^{18}$ Said Nursi, The Words, p. 491

${ }^{19}$ As quoted by Hasan Horkuc in Said Nursi's Ideal for Human Society, p.197.

${ }^{20}$ QS. al-Baqarah [2]: 219, 266.

${ }^{21}$ QS. al-A'rāf [7]:176, etc.

${ }^{22}$ QS. Rūm [30]: 8.

${ }^{23}$ QS. al-Ra'd [13):3, etc.

${ }^{24}$ Al-Ajlunī, Kashfu'l-Khafa, juz 1, np: Dār Ihyyā' Turāts al-'Arabī, p. 392; al-Ghazzali, Ihyyā' 'Ulūm al-Dīn ,juz 7, p. 93.

${ }^{25}$ Said Nursi, The Flashes, pp. 380-381.

${ }^{26}$ Said Nursi, The Rays, p. 172.

${ }^{27}$ Syed Farid Alatas, The Social Theology of Bediuzzaman Said Nursi and the Critique of Modern Civilization in Knowledge, Faith, Morality and the Future of Humanity, Ninth International Symposium on Bediuzzaman Said Nursi, 3 ${ }^{\text {rd }} 5^{\text {th }}$ October 2010, Istanbul Ofset, Istanbul 2010, p. 9 and p. 36.

${ }^{28}$ Said Nursi, The Signs of Miraculousness, p. 123.

${ }^{29}$ QS. al-Zumar [39]: 29, the similar to it is in al-Isrā [17]: 89, al-Ra'd [13]:17, Ibrāhīm [14]: 24, 45, al-Hajj [22]: 73, al-Rūm [30]: 28.

${ }^{30}$ Said Nursi, The Words, On the Nature and Purposes of Man, Life and All Things, p. 643.

${ }^{31}$ Syed Farid Alatas, The Social Theology, p. 36.

${ }^{32}$ Jane I Smith, "Similes and Metaphors of Life and Death in the Writings of Bediuzzaman Said Nursi," in Fifth International Symposium on Bediuzzaman Said Nursi the Qur'anic View of Man, According to the Rasā'il al-Nür (Sozler Nesriyat, 2000 ), p. 256.

${ }^{33}$ Ibid, p. 255.

${ }^{34}$ Said Nursi, The Words, p. 183

35Said Nursi, The Words, p. 185.

${ }^{36}$ Said Nursi, The Epitomes of Light, p. 249.

${ }^{37}$ Bilal Kuspinar, The Chief Characteristics of Spirituality in Said Nursi's Religious Thought, in Spiritual Dimensions of Bediuzzaman Said Nursi's Rasā'il al-Nūr, edited by Ibrahim M Abu Rabi, Albany, USA: State University of New York Press, 2008, pp. 141-142.

38Zuleyha Keskin, Overcoming Challenges In understanding Metaphysical and Spiritual Concepts, in Knowledge, Faith, Morality and the Future of Humanity, Ninth International Symposium on Bediuzzaman Said Nursi, $3^{\text {rd }} 5^{\text {th }}$ October 2010, Istanbul Ofset, Istanbul 2010, p. 484.

${ }^{39}$ Said Nursi, The Words, pp. 158-159.

${ }^{40} \mathrm{QS}$. al-Baqarah [2: 153.

${ }^{41}$ Al-'Ajluni, Kashfal-Khafa' juz 2, p. 21.

${ }^{42}$ QS. al-Baqarah [2]: 194.

${ }^{43}$ QS. Ali Imran [3]: 146.

${ }^{44} \mathrm{QS}$. Ali Imran [3]: 159.

${ }^{45}$ QS. Yūsuf [12]: 86.

${ }^{46}$ Said Nursi, Letters, p. 332.

${ }^{47}$ Said Nursi, The Words, p. 278.

48 Jalāl al-Dīn Abd al-Raḥman. b. Abī Bakr al-Suyūtī, al-Fatḥ al-Kabīr, Juzu 2, Beirut: Dār alFikr, 1423 H/2003, h. 190.

${ }^{49}$ Said Nursi, The Rays, Second Ray, First Station, pp.17-18, 192-193, The Words, p.695.

${ }^{50}$ Said Nursi, The Rays,The Supreme Sign, First Chapter p. 197.

${ }^{51}$ Said Nursi, The Flashes, Second Flash, pp. 26, 28, 334-336, The Words, pp.49, 185-190, The Letters, pp.64-65.

${ }^{52}$ QS. al-Baqarah [2]: 216.

${ }^{53}$ QS. al-Nisā [4]:19. 
${ }^{54}$ QS. al-Anbiyā [21]: 35.

${ }^{55}$ Said Nursi, The Letters, pp. 66-7

${ }^{56}$ Ibid., p. 441.

${ }^{57}$ Jamal al-Marzuqi, Moral Philosophy in the Qur'an from the Viewpoint of the Rasail al-Nur, in The Qur'anic View of Man, According to the Rasail al-Nur, Fifth International Symposium on Bediuzzaman Said Nursi, 24th-26 th September, 2000, Sozler Publication, Istanbul 2002, 279

${ }^{58}$ Musnad, I, p. 447; al-Munawī, Fayzh al-Qadīr, V, p. 454 no: 7939; al-Hindi, Kanz al'Ummal, III, p. 36; VI, p. 56, 57.

${ }^{59}$ Said Nursi, The flashes, p. 19.

${ }^{60}$ Sukran Vahide, 'The Life and Times of Bediuzzaman Said Nursi', in The Muslim World, Special Issue: Said Nursi and the Turkish Experience, 89th Volume, number 3-4, The Duncan Black Macdonald Center at Harford Seminary, July-October 1999, 210

61 Yvonne Yazbeck Haddad, Ghurbah as Paradigm for Muslim Life: a Risalei Nur, in The Muslim World, Special Issue: Said Nursi and the Turkish Experience, 89 th Volume, number 3-4, The Duncan Black Macdonald Center at Harford Seminary, July-October 1999, 300

${ }^{62} \mathrm{QS}$. al-A'rāf [7]: 176.

${ }^{63}$ QS. Yūsuf [12]: 111.

${ }^{64}$ Said Nursi, Signs of Miraculousness, p. 272.

${ }^{65}$ Said Nursi, The Words, p. 59.

66Ibid, 15.

${ }^{67}$ Ibid, 27.

${ }^{6}$ Ibid, 29.

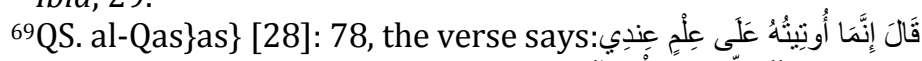

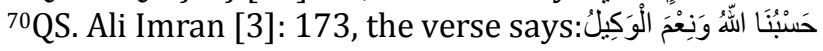

${ }^{71}$ Said Nursi, The Words, p. 337.

${ }^{72}$ QS. al-Anbiyā [21]: 83.

${ }^{73}$ Said Nursi, The Flashes, p. 21.

${ }^{74}$ Said Nursi, The Rays, p. 474.

${ }^{75}$ Ibid,p. 417.

${ }^{76}$ Said Nursi, The Letters, p. 334. 